\title{
EVALUASI KINERJA DAN KEMAMPUAN KEUANGAN DAERAH KOTA MAGELANG
}

\author{
Shania Nur Chasanah \\ shaniachasanah3@gmail.com \\ Jihad Lukis Panjawa \\ ijpanjawa@untidar.ac.id
}

\begin{abstract}
This study aims to analyze the performance and financial capability of Magelang City in the period 2014 - 2018. This study uses a quantitative approach with secondary data. The analytical tool used to measure the financial performance of the City of Magelang is a ratio and to calculate the financial capacity of the region measured by the index Share, Growth, Elasticity. The results showed the city of Magelang entered the category of low. The level of regional financial dependency shows a very high level of dependency. The degree of fiscal decentralization is in the moderate category. The level of effectiveness of regional income is very effective. The results of the calculation of the regional financial performance index (IKK) show that financial capacity is relatively high. Other findings from the mapping of regional financial capacity based on the quadrant method, the position of the city of Magelang is in quadrant III. This condition is also not ideal. The big role of PAD in Total Spending has a small chance because the growth of PAD is small. The contribution of PAD to total expenditure is high, but the growth of PAD is low. Efforts to further increase PAD by optimizing resource management and expanding the potential of the economic sector.
\end{abstract}

Keywords : Financial Performance, Financial Ability, Share, Growth, Elasticity

\section{PENDAHULUAN}

Pengertian otonomi daerah menurut Undang- undang Nomor 22 Tahun 1999 yang kemudian menjadi UU No.32 Tahun 2004 tentang Otonomi daerah (Otda) adalah kewenangan daerah otonom untuk mengatur dan mengurus kepentingan masyarakat setempat menurut prakarsa sendiri berdasarkan aspirasi masyarakat sesuai peraturan perundang-undangan sedangkan menurut Simanjuntak (2013) mendefinisikan otonomi daerah adalah bagaimana pemerintah daerah dapat mengelola daerah dengan baik, tidak ada kesenjangan antara masyarakat dengan pemerintah, dengan masyarakat sendiri guna mencapai tujuan yang tidak menyimpang dari peraturan perundang-undang. Salah satu cara untuk mengelola dana adalah dengan Menyusun anggaran untuk patokan dalam melaksanakan setiap kegiatan. Anggaran merupakan bagian penting dalam system pengendalian manajemen yang disusun organisasi dalam mencapai tujuan. Pada sektor publik, anggaran merupakan dokumen publik yang bisa diakses oleh publik untuk diketahui, 
diberi masukan, dikritisi dan diperdebatkan. Anggaran sektor publik merupakan blue print organisasi tentang rencana program dan kegiatan yang akan dilaksanakan (Mahmudi, 2011). Analisis kinerja keuangan bertujuan untuk mengukur dan mengevaluasi kinerja pemerintah, mengukur potensi mendapatkan atau sumber ekonomi, mengetahui konsisi keuangan, mengetahui kemampuan pemerintah dalam memenuhi kewajibannya, dan menyakini bahwa pemerintah telah melaksanakan anggaran sesuai dengan peraturan perundang-undangan. Salah satu alat untuk menganalisis kinerja keuangan adalah dengan rasio keuangan. Mahmudi (2010) analisis rasio keungan terdiri dari derajat desentralisasi, rasio ketergantungan keuangan.

Kota Magelang merupakan daerah strategis yang terletak pada persilangan jalur transportasi utama Semarang-Yogyakarta, jalur kegiatan ekonomi Semarang-YogyakartaPurworejo dan jalur wisata Yogyakarta Borobudur Kopeng dan dataran tinggi Dieng. Sumber daya alam yang berada di Kota Magelang memang tidak begitu kaya, akan tetapi memiliki potensi daerah yang mampu dioptimalkan untuk menunjang peningkatan PAD. Tidak hanya sumber daya alam saja yang harus dioptimalkan, tetapi pendapatan daerah juga dialokasikan sehingga menjadi sumber dalam peningkatan PAD. Pendapatan Asli Daerah (PAD) yang dikelola diharapkan mampu mengurangi ketergantungan dari pusat. Dalam hal ini pemerintah daerah mempunyai peluang untuk membangun dan mengembangkan daerahnya sesuai kebutuhan dan kemampuan daerah. Berikut ini adalah data Realisasi Pendapatan Asli Daerah (PAD) enam kota di Provinsi Jawa Tengah :

Tabel 1.

Data Realisasi PAD enam kota di Provinsi Jawa Tengah Tahun 2014-2018

\begin{tabular}{|c|c|c|c|c|c|c|}
\hline \multirow{2}{*}{ NO } & \multirow{2}{*}{ KOTA } & \multicolumn{5}{|c|}{ Pendapatan Asli Daerah (PAD) } \\
\cline { 3 - 7 } & & \multicolumn{5}{|c|}{ Tahun } \\
\cline { 3 - 7 } & & 2014 & 2015 & 2016 & 2017 & 2018 \\
\hline 1 & Kota Magelang & $164,927,631,230$ & $186,677,410,081$ & $220,315,425,999$ & $233,557,714,356$ & $249,877,424,347$ \\
\hline 2 & Kota Pekalongan & $144,065,424,017$ & $152,044,596,332$ & $178,604,460,870$ & $192,002,871,181$ & $179,224,408,698$ \\
\hline 3 & Kota Salatiga & $165,747,645,080$ & $167,010,555,173$ & $203,768,690,069$ & $220,243,361,132$ & $208,926,057,032$ \\
\hline 4 & Kota Semarang & $1,138,367,228,493$ & $1,201,581,778,459$ & $1,491,647,979,748$ & $1,791,886,378,674$ & $1,821,274,103,250$ \\
\hline 5 & Kota Surakarta & $335,660,206,641$ & $372,798,426,790$ & $425,502,766,156$ & $527,544,224,971$ & $527,739,388,159$ \\
\hline 6 & Kota Tegal & $241,936,166,929$ & $271,601,407,419$ & $287,343,472,844$ & $306,830,656,135$ & $275,021,448,594$ \\
\hline
\end{tabular}


Sumber: djpk kemenkeu

Dari data PAD enam kota yang ada di Provinsi Jawa Tengah, bisa dilihat bahwa rata rata PAD tersebut mengalami peningkatan dari tahun 2014-2018. Akan tetapi, kota dengan Pendapatan Asli Daerah (PAD) paling tinggi adalah Kota Semarang dimana pada tahun 2018 sebesar 1,821,274,103,250. Kota Magelang merupakan salah satu kota di Provinsi Jawa Tengah yang Pendapatan Asli Daerah (PAD) nya dari tahun ke tahun selalu meningkat, capaian tersebut didukung oleh pemasukan dari pajak daerah, hasil pengelolaan kekayaan daerah yang dipisahkan, retribusi daerah, dan sumber PAD lain yang sah. Selain itu, bisa juga didorong agar setiap orang di Kota magelang memiliki jiwa entrepreneur sehingga Kota magelang dapat menjadi layak jual dan memiki kualitas yang baik dengan begitu masyarakat dalam daerah ataupun luar daerah memliki ketertarikan untuk datang ke Kota Magelang.

Otonomi daerah merupakan konsep pembangunan ekonomi berbasis desentralisasi di Indonesia, dimana adanya pemberian kewenangan secara luas bagi Pemerintah Daerah (Pemda) untuk melakukan pembaharuan terhadap sistem pengelolaan daerah dan anggaran daerah. Penerapan otonomi daerah diharapkan agar setiap daerah mampu menggali dan mengembangkan potensi daerah yang dimiliki sehingga mampu memperoleh pendapatan dan membiayai daerahnya yang akan menentukan keberhasilan penerapan kebijakan otonomi daerah tersebut (Sanusi dan Irman, 2012).

Pengelolaan Keuangan Daerah mengandung arti bahwa setiap daerah otonom dapat mengurus dan mengatur keuangannya sendiri dengan menggunakan prinsi- prinsip pengelolaan keuangan daerah menurut Mardiasmo (2002) antara lain : Transparansi, Akuntabilitas, Value of Money.

Menurut Halim (2009), ruang lingkup keuangan daerah terdiri dari keuangan daerah yang dikelola langsung dan kekayaan daerah yang dipisahkan. Yang termasuk dalam keuangan daerah yang dikelola langsung adalah Anggaran Pendapatan dan Belanja Daerah (APBD) dan barang-barang inventaris milik daerah. Keuangan daerah yang dipisahkan meliputi 
Badan Usaha Milik Daerah (BUMD). Menurut Losa (2012) Kemampuan mengelola keuangan daerah tercantum dalam laporan APBD yang menggambarkan kemampuan dalam membiayai penyelenggaraan kegiatan Pemda beserta pembangunannya dengan menggunakan seluruh potensi yang dimiliki.

Dalam penelitian ini, penulis memilih Kota Magelang sebagai obyek penelitian terhadap kinerja keuangan pemerintah daerah dan tingkat kesejahteraan masyarakat. Penulis juga ingin memberikan kontribusi terhadap perkembangan dan kemajuan daerah Kota Magelang dengan mengkaji kinerja pemerintah daerah dan kesejahteraan masyarakat sehingga dapat memberikan masukan dan saran-saran demi perbaikan kinerja pemerintah daerah dan kesejahteraan masyarakat di Kota Magelang ke arah yang lebih baik.

Meskipun tidak punya sumber daya alam, Kota Magelang mampu konsisten menaikkan PAD nya selama lima tahun terakhir. Dengan tidak adanya sumber daya alam, Pemerintah Daerah Kota Magelang mampu mendorong PAD salah satunya dengan meningkatkan kesadaran masyarakat membayar pajak dengan salah satu buktinya berupa realisasi penerimaan pajak bumi bangunan perkotaan dan pedesaan (PBB-P2) yang meningkat setiap tahun. Hal ini juga akan berimbas terhadap kondisi kinerja dan kemampuan pemerinta kota Magelang dalam hal mengatasi keuangan daerah Kota Magelang. Tujuan penelitian ini adalah untuk mengevaluasi kinerja dan kemampuan keuangan daerah Kota Magelang. Berdasarkan masalah di atas penulis tertarik untuk melakukan penelitian dengan judul "Evaluasi Kinerja dan Kemampuan Keuangan Daerah Kota Magelang Tahun 2014-2018". Penelitian ini di fokuskan untuk mengevaluasi kinerja dan kemampuan keuangan daerah Kota Magelang.

\section{LANDASAN TEORI}

\section{KINERJA KEUANGAN DAERAH}

Menurut Syamsi dalam Herisistam (2015) Kinerja keuangan daerah adalah kemampuan suatu daerah untuk menggali dan mengelola sumber-sumber keuangan asli daerah daerah guna memenuhi kebutuhannya guna mendukung berjalannya roda 
pemerintahan, pelayanan kepada masyarakat, dan pembangunan daerahnya dengan tidak tergantung sepenuhnya kepada pemerintah pusat dalam bentuk dana perimbangan dan mempunyai keleluasaan dalam menggunakan dana tersebut untuk kepentingan masyarakat daerah dalam batas-batas yang diatur dan ditentukan berdasarkan peraturan perundang-undangan.

Penilaian kerja (performance appraisal) pada dasarnya merupakan factor kunci guna mengembangkan suatu organisasi secara efektif dan efisien, karena adanya kebijakan atau program yang lebih bai katas sumber daya manusia yang ada dalam organisasi penilaian kerja individu sangat bermanfaat bagi dinamika pertumbuhan organisasi secara keseluruhan, melalui penilian tersebut maka dapat diketahui kondisi sebenarnya tentang bagimana kinerja lembaga (Rusydi, 2010).

Menurut Mardiasmo (2002), pengukuran kinerja keuangan Pemerintah Daerah dilakukan untuk memenuhi 3 tujuan yaitu memperbaiki kinerja pemerintah, membantu mengalokasikan sumber daya dan pembuatan keputusan dan mewujudkan pertanggung jawaban publik dan memperbaiki komunikasi kelembagaan.

\section{Anggaran Pendapatan dan Belanja Daerah (APBD)}

Menurut Moh. Mahsun, dkk, 2011: 81, Anggaran Pendapatan dan Belanja Daerah adalah daftar yang memuat rincian penerimaan daerah dan pengeluaran/ belanja daerah selama satu tahun. Anggaran Pendapatan dan Belanja Daerah ditetapkan dengan peraturan daerah untuk masa satu tahun, mulai dari 1 Januari sampai dengan tanggal 31 Desember. Dalam Peraturan Menteri Dalam Negeri Republik Indonesia Nomor 37 Tahun 2014 Tentang Pedoman Penyusunan Anggaran Pendapatan dan Belanja Daerah Tahun Anggaran 2015 Pasal 1 Ayat 1, pengertian Anggaran Pendapatan dan Belanja Daerah adalah rencana keuangan tahunan pemerintahan daerah yang dibahas dan disetujui bersama oleh Pemerintah Daerah dan DPRD, dan ditetapkan dengan peraturan daerah.

Menurut Halim (2012), pada era orde lama terdapat pula definisi APBD yang dikemukakan oleh Wajong, 1962: 81, yaitu rencana pekerjaan keuangan (financial 
workplan) yang dibuat untuk suatu jangka waktu tertentu, ketika badan legislatif (DPRD) memberikan kredit kepada badan eksekutif (kepala daerah) untuk melakukan pembiayaan kebutuhan rumah tangga daerah sesuai dengan rancangan yang menjadi dasar (grondslag) penetapan anggaran, dan yang menunjukkan semua penghasilan untuk menutup pengeluaran tadi.

\section{Analisis Laporan Keuangan}

Fungsi utama laporan keuangan pemerintah daerah adalah untuk memberikan informasi keuangan kepada pihak-pihak yang berkepentingan sebagai dasar pengambilan keputusan. Tetapi tidak semua pengguna laporan keuangan memahami akuntansi dengan baik, sementara mereka akan mengandalkan informasi keuangan itu untuk membuat keputusan. Untuk membantu mengatasi ketidakmampuan memahami dan menginterpretasikan laporan keuangan tersebut, maka perlu dibantu dengan Analisis Laporan Keuangan. Menganalisis laporan keuangan berarti menggali lebih banyak informasi yang dikandung suatu laporan keuangan. Analisis laporan keuangan diperlukan untuk penguasaan terhadap cara menyusun laporan keuangan itu (proses akuntansi), konsep, sifat, karakteristik laporan keuangan atau akuntansi itu, teknik analisisnya, segmen, dan sifat bisnis itu sendiri, serta situasi lingkungan ekonomi, baik internasional maupun nasional.

\section{PENELITIAN TERDAHULU}

Penelitian yang dilakukan I Dewa Gede Bisma dan Hery Susanto (2010) yang berjudul "Evaluasi Kinerja Keuangan Daerah Pemerintah Provinsi Nusa Tenggara Barat Tahun Anggaran 2003-2007", dengan alat analisis rasio keuangan daerah dipeloeh hasil bahwa ketergantungan keuangan daerah sangat tinggi terhadap pemerintah pusat sehingga tingkat kemandirian daerah sangat kurang. Desentralisasi fiskal cukup mengingat ketergantungan keuangan terhadap pemerintah pusat sangat tinggi. Efektifitas pengelolaan anggaran pendapatan dan belanja daerah (APBD) sangat efektif, namun efisiensi pengelolaan anggaran pendapatan dan belanja daerah (APBD) menunjukkan hasil tidak efisien. 
Penelitian yang dilakukan Muhammad Wahyudi \& Eva Wulandari (2017) yang berjudul “Kinerja Keuangan Pemerintah Daerah Dalam Era Otonomi Daerah (Studi Kasus Pemerintah Daerah Kota Magelang)" disimpulkan bahwa, rata-rata kinerja keuangan daerah yang belum stabil atau belum begitu baik. Dimana hasil perhitungan setiap tahun mengalami trend yang positif dan trend yang negatif. Hal ini disebabkan Pemerintah Kota Magelang masih kurang mampu dalam menciptakan kemandirian dan kemampuan pemerintah dalam membiayai sendiri kegiatan pemerintahan, pembangunan dan pelayanan kepada masyarakat. Ini dapat dijelaskan dari hasil penelitian yang mengguanakan beberapa rasio keuangan antara lain rasio kemandirian, rasio derajat desentrali fiskal, rasio efektifitas, rasio efisiensi, rasio keserasian belanja, serta dengan analisis kemampuan keuangan daerah.

Penelitian yang dilakukan Agung Slamet Sukardi (2014) yang berjudul "Evaluasi Kinerja keuangan Daerah Kota Bandung Tahun Anggaran 2010-2014" menarik kesimpulan bahwa dari hasil perhitungan Indeks kemampuan keuangan kota Bandung tahun anggaran 2010 sampai dengan 2014, skala indeks menunjukkan angka 62,736. Ini berarti kemampuan keuangan kota Bandung tergolong tinggi. Kemudian, jika dari hasil perhitungan share dan growth terhadap ringkasan anggaran pendapatan dan belanja daerah kota Bandung tahun anggaran 2010 sampai dengan 2014, maka diperoleh data share sebesar 59,926\% dan growth sebesar 58,983\%. Posisi kota Bandung berada pada kuadran II.

Penelitian yang dilakukan oleh Mahmud, Kawung dan Rompas (2014) menemukan hasil bahwa kinerja keuangan Pemerintah daerah di Provinsi Sulawesi Utara masih menunjukkan rata-rata kinerja keuangan daerah yang masih belum stabil serta tingkat ketergantungan daerah terhadap pemerintah pusat masih sangat tinggi. Sementara Bisma dan Susanto (2010) menemukan hasil bahwa kinerja keuangan Pemerintah Provinsi Nusa Tenggara Barat Tahun Anggaran 2003-2007 tidak optimal. Hal ini ditunjukkan oleh indikator kinerja keuangan antara lain; ketergantungan keuangan daerah terhadap pemerintah pusat sangat tinggi, efektivitas pengelolaan APBD sangat efektif, namun efisiensi pengelolaan APBD menunjukkan hasil tidak efisien. 


\section{METODE PENELITIAN}

1. Jenis Penelitian

Penelitian ini menggunakan metode studi kasus dengan pendekatan deskriptif. Metode deskriptif yaitu suatu metode dalam meneliti status sekelompok manusia, suatu objek, suatu set kondisi, suatu sistem pemikiran ataupun suatu peristiwa pada masa sekarang yang bertujuan untuk membuat deskripsi, gambaran atau lukisan secara sistematis, faktual dan akurat mengenai fakta-fakta, sifat-sifat serta hubungan antar fenomena yang diselidiki.

2. Jenis dan Sumber Data

Jenis data yang digunakan dalam penelitian ini adalah data sekunder. Data sekunder biasanya telah dikumpulkan oleh lembaga pengumpul data dan dipublikasikan kepada masyarakat pengguna data Kuncoro (2009). Data sekunder dalam penelitian ini yaitu data Ringkasan Laporan Realisasi APBD tahun 2014-2018. Data ini diperoleh melalui Badan Pengelola Keuangan dan Aset Daerah (BPKAD) dan dari situs Dirjen Perimbangan Keuangan Pemerintah Daerah.

3. Variabel Penelitian

Variabel yang digunakan dalam peneltian mengenai evaluasi kinerja keuangan dan kemampuan keuangan daerah Kota Magelang tahun 2014-2018 adalah Total Pendapatan Daerah, Pendapatan Asli Daerah (PAD), Dana Perimbangan, Total Belanja Daerah, dan Pertumbuhan Ekonomi (Growth).

4. Teknik Pengumpulan Data

Teknik yang digunakan dalam mengumpulkan data dalam penelitian ini adalah teknik studi lapangan yaitu melakukan penelitian ke kantor pemerintah kota Magelang dan mewawancarai langsung kepada bidang akuntansi dalam guna untuk mendapatkan Laporan Realisasi Anggaran. Data tersebut diperoleh dari Badan Pengelola Keuangan dan Aset Daerah (BPKAD). 
5. Teknik Analisis Data

Penelitian ini merupakan penelitian deskriptif. Menurut Setyosari (2002) penelitian deskriptif adalah penelitian yang bertujuan untuk menjelaskan atau mendeskripsikan suatu keadaan, peristiwa, objek apakah orang atau segala sesuatu yang terkait dengan variabel-variebel yang bisa dijelaskan baik dengan angka-angka maupun kata-kata dengan menggambarkan dan menganalisis obyek penelitian. Objek penelitian ini adalah kinerja keuangan daerah pemerintah kota Magelang tahun anggaran 2014-2018.

Salah satu teknik untuk untuk melakukan Analisis Laporan Keuangan, yaitu dengan melakukan perhitungan Analisis Rasio Keuangan. Laporan Realisasi Anggaran Pendapatan dan Belanja Daerah Tahun Anggaran 2014-2018. Analisis Rasio Keuangan digunakan untuk menghitung Analisis Kinerja Keuangan Daerah dan Kemampuan Keuangan Daerah.

1. Analisis Kinerja Keuangan

Analisis Kinerja Keuangan adalah usaha mengidentifikasi ciri-ciri keuangan berdasarkan laporan keuangan yang tersedia. Dalam organisasi pemerintah untuk mengukur kinerja keuangan ada beberapa ukuran kinerja, yaitu :

a). Rasio Kemandirian Keuangan Daerah

Halim (2012) menyatakan bahwa Rasio Kemandirian menggambarkan ketergantungan daerah terhadap sumber dana eksternal. Semakin tinggi Rasio Kemandirian, mengandung arti bahwa tingkat ketergantungan daerah terhadap bantuan pihak eksternal (terutama pemerintah pusat dan provinsi) semakin rendah. Demikian pula sebaliknya, semakin rendah Rasio Kemandirian, semakin rendah tingkat partisipasi masyarakat dalam membayar pajak dan retribusi daerah yang merupakan komponen utama Pendapatan Asli Daerah (PAD). Semakin tinggi masyarakat membayar pajak dan retribusi daerah akan menggambarkan tingkat kesejahteraan masyarakat yang semakin meningkat. 


$$
\text { Rasio Kemandirian }=\frac{\text { Pendapatan Asli daerah }(\mathrm{PAD})}{\text { Dana Perimbangan }} \times 100 \%
$$

Tabel 2.

Kriteria Penilaian Kemandirian Daerah

\begin{tabular}{|l|l|}
\hline \multicolumn{1}{|c|}{$\begin{array}{c}\text { Prosentasi PAD terhadap } \\
\text { Dana Perimbangan }\end{array}$} & \multicolumn{1}{|c|}{$\begin{array}{c}\text { Kemandirian Keuangan } \\
\text { Daerah }\end{array}$} \\
\hline $0,00-10,00$ & sangat baik \\
\hline $10,01-20,00$ & baik \\
\hline $20,01-30,00$ & Cukup \\
\hline $30,01-40,00$ & Sedang \\
\hline $40,01-50,00$ & Kurang \\
\hline$>50$ & sangat kurang \\
\hline
\end{tabular}

Sumber : Tim Litbang Depdakgri-Fisipol UGM, 1991

b). Rasio Ketergantungan Keuangan Daerah

Tingkat ketergantungan daerah adalah ukuran tingkat kemampuan daerah dalam membiayai aktifitas pembangunan daerah melalui optimalisasi PAD, yang diukur dengan rasio antara dana perimbangan terhadap pendapatan daerah dengan formulasi sebagai berikut.

$$
\text { Rasio ketergantungan }=\frac{\text { Dana perimbangan }}{\text { Pendapatan Derah }} \times 100 \%
$$

Tabel 3.

Kriteria Penilaian Ketergantungan Daerah

\begin{tabular}{|l|l|}
\hline $\begin{array}{c}\text { Prosentasi PAD terhadap } \\
\text { Total penerimaan non } \\
\text { subsidi }\end{array}$ & \multicolumn{1}{|c|}{$\begin{array}{c}\text { Ketergantugan keuangan } \\
\text { daerah }\end{array}$} \\
\hline $0,00-10,00$ & Sangat Rendah \\
\hline $10,01-20,00$ & Rendah \\
\hline $20,01-30,00$ & Sedang \\
\hline $30,01-40,00$ & Cukup \\
\hline $40,01-50,00$ & Tinggi \\
\hline$>50$ & Sangat tinggi \\
\hline
\end{tabular}

Sumber : Tim Litbang Depdakgri-Fisipol UGM, 1999

c). Rasio Derajat Desentralisasi Fiskal 
Rasio Derajat Desentralisasi Fiskal adalah ukuran yang menunjukkan tingkat kewenangan dan tanggung jawab yang diberikan pemerintah pusat kepada pemerintah daerah untuk melaksanakan pembangunan. Menurut Mahmudi (2010), derajat desentralisasi dihitung berdasarkan perbandingan antara jumlah Pendapatan Asli Daerah dengan Total Penerimaan Daerah. Semakin tinggi kontribusi PAD, semakin tinggi juga kemampuan pemerintah daerah dalam penyelenggaraan desentralisasi.

$$
\text { Rasio Desentralisasi Fiskal }=\frac{\text { Pendapatan Asli daerah }(\mathrm{PAD})}{\text { Pendapatan Daerah }} \times 100 \%
$$

Tabel 4.

Kriteria Penilaian Tingkat Desentralisasi Fiskal

\begin{tabular}{|l|l|l|}
\cline { 2 - 3 } & Prosentasi PAD terhadap TPD & Tingkat Desentralisasi Fiskal \\
\hline & $0,00-10,00$ & Sangat kurang \\
\hline $10,01-20,00$ & Kurang \\
\cline { 2 - 3 } & $20,01-30,00$ & Sedang \\
\cline { 2 - 3 } d). Rasio & $30,01-40,00$ & Cukup \\
\cline { 2 - 3 } Efektivitas PAD & $40,01-50,00$ & Baik \\
\cline { 2 - 3 } & $>50$ & Sangat Baik \\
\cline { 2 - 3 } & &
\end{tabular}

Halim

Sumber : Tim Litbang Depdakgri-Fisipol UGM, 1991

menyatakan bahwa Rasio Efektivitas menggambarkan kemampuan Pemerintah Daerah dalam merealisasikan Pendapatan Asli Daerah (PAD) yang direncanakan, kemudian dibandingkan dengan target yang ditetapkan berdasarkan potensi riil daerah. Semakin tinggi Rasio Efektivitas menggambarkan kemampuan daerah yang semakin baik.

$$
\text { Rasio Efektifitas }=\frac{\text { Realisasi pendapatan asli daerah }}{\text { Target penerimaan pendapatan asli daerah }} \times 100 \%
$$

Tabel 5.

Kriteria Penilaian Efektifitas Pengelolaan Keuangan Daerah

\begin{tabular}{|l|l|}
\hline Prosentasi Kinerja Keuangan & \multicolumn{1}{c|}{ Kriteria } \\
\hline Diatas $100 \%$ & Sangat Efektif \\
\hline $90 \%-100 \%$ & Efektif \\
\hline $80 \%-90 \%$ & Cukup Efektif \\
\hline $60 \%-80 \%$ & Kurang Efektif \\
\hline Dibawah $60 \%$ & Tidak Efektif \\
\hline
\end{tabular}


Sumber: Depdagri, Kepmendagri No.690.900.327 Tahun 1996

2. Analisis Kemampuan Keuangan Daerah

a) Perhitungan dan Analisis Share dan Growth

Diawali dengan perhitungan dan Analisis Kinerja PAD melalui ukuran Share dan Growth kemudian mengklasifikasikan dengan Pemetaan Kemampuan Keuangan Daerah berdasarkan Metode Kuadran.

Tabel 6.

Klasifikasi Status Kemampuan Keuangan

\begin{tabular}{|c|l|}
\hline KUADRAN & KONDISI \\
\hline I & $\begin{array}{l}\text { Kondisi paling ideal. PAD mengambil peran besarldalam total } \\
\text { belanja, dan daerah mempunyai kemampuan } \\
\text { mengembangkan potensi lokal. Kondisi ini ditunjukkan } \\
\text { dengan besarnya nilai share dan growth yang tinggi. }\end{array}$ \\
\hline II & $\begin{array}{l}\text { Kondisi ini belum ideal, tetapi daerah mempunyai } \\
\text { kemampuan mengembangkan potensi lokal sehinga PAD } \\
\text { berpeluang memiliki peran besar dalam Total Belanja. } \\
\text { Sumbangan PAD terhadap Total Belanja masih rendah } \\
\text { namun pertumbuhan (growth) PAD tinggi. }\end{array}$ \\
\hline III & $\begin{array}{l}\text { Kondisi ini juga belum ideal. Peran PAD yang besar dalam } \\
\text { Total Belanja mempunyai peluang yang kecil karena } \\
\text { pertumbuhan PAD nya kecil. Sumbangan PAD terhadap } \\
\text { Total Belanja tinggi, namun pertumbuhan PAD rendah. }\end{array}$ \\
\hline IV & $\begin{array}{l}\text { Kondisi ini paling buruk. Peran PAD belum mengambil peran } \\
\text { yang besar dalam Total Belanja, dan daerah belum } \\
\text { mempunyai kemampuan mengembangkan potensi lokal. } \\
\text { Sumbangan PAD terhadap Total Belanja dan pertumbuhan } \\
\text { PAD rendah }\end{array}$ \\
\hline
\end{tabular}

Sumber: Bapenas 2003

$$
\begin{aligned}
& \text { share }=\frac{\text { PAD }}{\text { Total belanja }} \times 100 \% \\
& \text { Growth }=\frac{\text { PADi }}{\text { PADi }-1} \times 100 \%
\end{aligned}
$$

b). Menghitung Indeks Kemampuan Keuangan (IKK)

Menghitung Indeks Kemampuan Keuangan kemudian mengklasifikasikan dengan metode Indeks Kemampuan Keuangan. Metode Indeks Kemampuan Keuangan merupakan rata-rata hitung dari Indeks Pertumbuhan (Growth), Indeks 
Elastisitas dan Indeks Share. Untuk menyusun indeks ketiga komponen tersebut, ditetapkan nilai maksimum dan minimum dari masing-masing komponen. Menyusun indeks untuk setiap komponen IKK dilakukan dengan menggunakan persamaan umum:

Index $X=\frac{\text { nilai } x \text { hasil pengukuran }- \text { nilai } \mathrm{x} \text { minimum }}{\text { nilai } x \text { maxsimum }- \text { nilai } x \text { minimum }} \times 100 \%$

Berdasarkan persamaan di atas, maka persamaan IKK dapat ditulis sebagai berikut:

$$
\begin{aligned}
& \mathrm{IKK}=\frac{X G+X E+X S}{3} \\
& \mathrm{XG}=\text { Indeks Pertumbuhan (PAD) } \\
& \mathrm{XE}=\text { Indeks Elastisitas (Belanja Langsung Terhadap PAD) } \\
& \mathrm{XS}=\text { Indeks Share (PAD terhadap APBD) }
\end{aligned}
$$

Tabel 7.

Kriteria Tingkat Kemampuan Keuangan Daerah

\begin{tabular}{|l|l|}
\hline \multicolumn{1}{|c|}{ Indeks Kemampuan Keuang Daerah } & \multicolumn{1}{|c|}{ Klasifikasi } \\
\hline $0,00-0,33$ & Rendah \\
\hline $0,34-0,43$ & Sedang \\
\hline $0,41-1,00$ & Tinggi \\
\hline
\end{tabular}

Sumber: Bappenas, 2003

\section{HASIL PENELITIAN DAN PEMBAHASAN}

Objek penelitian ini adalah kinerja keuangan daerah pemerintah kota Magelang tahun anggaran 2014-2018. Adapun hasil pengolahan dari data rasio kemandirian keuangan daerah, rasio tingkat kemandirian daerah, tingkat ketergantungan daerah, tingkat desentralisasi fiskal dan tingkat efektivitas PAD adalah sebagai berikut :

1. Rasio kemandirian keuangan daerah

Kemandirian keuangan daerah (otonomi fiskal) menunjukan kemampuan pemerintah daerah dalam membiayai sendiri kegiatan pemerintahan. Rasio 
Kemandirian dihitung dengan cara perbandingan antara Pendapatan Asli Daerah dengan Bantuan Pemerintah Pusat atau Propinsi dan Pinjaman.

Hasil perhitungan tingkat kemandirian keuangan daerah kota Magelang dapat dilihat pada tabel 8.

Tabel 8.

Rasio Tingkat Kemandirian Keuangan Daerah Kota Magelang 2014-2018

\begin{tabular}{|c|c|c|c|}
\hline Tahun & Pad (Rp) & Dana Perimbangan & Rasio Kemandirian \% \\
\hline 2014 & $164,927,631,230$ & $459,785,205,171$ & 35.87 \\
\hline 2015 & $186,677,410,081$ & $462,804,716,465$ & 40.34 \\
\hline 2016 & $220,315,848,702$ & $567,636,707,545$ & 38.81 \\
\hline 2017 & $233,557,714,356$ & $553,115,007,612$ & 42.23 \\
\hline 2018 & $249,877,424,347$ & $570,455,641,253$ & 43.80 \\
\hline Rata-Rata & & & 40.21 \\
\hline
\end{tabular}

Sumber: data sekunder yang diolah

Berdasarkan tabel diatas dapat diketahui bahwa rasio kemandirian kota Magelang mengalami peningkatan dari tahun ke tahun. Rata-rata tingkat kemandirian keuangan daerah kota Magelang tahun anggaran 2014 sampai dengan tahun 2018 adalah sebesar 40,21\%. Ini berarti bahwa kontribusi pendapatan asli daerah terhadap total pendapatan terhadap APBD masih kecil dibandingkan peran dari pemerintah pusat/provinsi yang masih sangat besar dalam APBD yang dapat dilihat dari besarnya penerimaan yang berasal dari transfer pemerintah pusat/provinsi. Hal ini menunjukan bahwa ketergantungan pemerintah daerah kota Magelang pada pemerintah pusat/provinsi masih sangat besar, pemerintah daerah belum mampu mencukupi kebutuhan daerahnya sendiri.

\section{Rasio Ketergantungan Keuangan Daerah}

Kemajuan suatu daerah bisa terlihat dari aktifitas pembangunan baik dari infrastruktur, sarana dan prasaran yang di butuhkan untuk menunjang suatu kegiatan pemerintah dengan mengoptimalisasi pendapatan asli daerah tersebut yang terlihat dari rasio dana perimbangan terhadap pendapatan daerah. 
Hasil perhitungan tingkat ketergantungan keuangan daerah kota Magelang tahun anggaran 2014-2018 dapat dilihat pada tabel 9.

Tabel 9.

Rasio Tingkat Ketergantungan Keuangan Daerah Kota Magelang 2014-2018

\begin{tabular}{|c|c|c|c|}
\hline Tahun & Dana Perimbangan & Pendapatan Daerah & Rasio Ketergantungan \% \\
\hline 2014 & $459,785,205,171$ & $735,116,114,407$ & 62.55 \\
\hline 2015 & $462,804,716,465$ & $781,335,799,509$ & 59.23 \\
\hline 2016 & $567,636,707,545$ & $840,042,626,525$ & 67.57 \\
\hline 2017 & $553,115,007,612$ & $909,525,862,920$ & 60.81 \\
\hline 2018 & $570,455,641,253$ & $908,089,485,909$ & 62.82 \\
\hline Rata-Rata & & & 62.60 \\
\hline
\end{tabular}

Sumber: data sekunder yang diolah

Berdasarkan tabel diatas dapat diketahui bahwa rasio ketergantungan kota Magelang berfluktuatif. Rata-rata tingkat ketergantungan daerah kota Magelang tahun anggaran 2014 sampai dengan tahun 2018 adalah sebesar 62,60\%. Sehingga diklasifikasikan dalam kategori tingkat ketergantungan keuangan yang sangat tinggi. Hal ini mengindikasikan tingkat ketergantungan Kota Magelang masih tinggi terhadap pemerintah pusat melalui dana perimbangan.

3. Rasio Derajat Desentralisasi Fiskal

Derajat Desentralisasi Fiskal adalah kemampuan pemerintah daerah dalam rangka meningkatkan Pendapatan Asli daerah guna membiayai pembangunan. Derajat Desentralisasi Fiskal, diukur dengan cara PAD dibandingkan dengan Pendapatan Daerah. Keberhasilan pelaksanaan Tingkat kewenangan dan tanggung jawab yang diberikan pemerintah pusat kepada daerah untuk melaksanakan suatu pembagunan dapat kita lihat dari rasio PAD terhadap pendapatan daerah.

Hasil perhitungan tingkat desentralisasi fiskal kota Magelang tahun anggaran 2014-2018 dapat dilihat di tabel 10

Tabel 10.

Rasio Tingkat Desentralisasi Fiskal Daerah Kota Magelang 2014-2018 


\begin{tabular}{|c|c|c|c|}
\hline & $(\mathrm{Rp})$ & & \\
\hline 2014 & $164,927,631,230$ & $735,116,114,407$ & 22.44 \\
\hline 2015 & $186,677,410,081$ & $781,335,799,509$ & 23.89 \\
\hline 2016 & $220,315,848,702$ & $840,042,626,525$ & 26.23 \\
\hline 2017 & $233,557,714,356$ & $909,525,862,920$ & 25.68 \\
\hline 2018 & $249,877,424,347$ & $908,089,485,909$ & 27.52 \\
\hline Rata-Rata & & & 25.15 \\
\hline
\end{tabular}

Sumber : data sekunder yang diolah

Berdasarkan tabel diatas dapat diketahui bahwa rasio derajat desentralisasi fiskal kota Magelang cenderung mengalami kenaikan. Rata-rata tingkat DDF kota Magelang tahun anggaran 2014 sampai dengan tahun 2018 adalah sebesar 25,15\% sehingga pemerintah kota Magelang termasuk dalam kategori sedang. Hal ini menunjukkan bahwa kemampuan keuangan daerah semakin baik yang mana kontribusi PAD dalam menopang pendapatan daerah, serta peran PAD atau kemampuan keuangan daerah untuk membiayai pembangunannya sendiri kurang dari $50 \%$.

4. Rasio Efektifitas Pendapatan Asli Daerah

Tingkat efektifitas suatu daerah terlihat dari pencapaian tujuan realisasi pendapatan dan target-target yang dicapai dalam suatu periode kepemerintahan daerah yang diukur melalui rasio pendapatan daerah terhadap target pendapatan daerah.

Hasil perhitungan tingkat efektifitas keuangan daerah kota Magelang tahun anggaran 2014-2018 dapat dilihat pada tabel 11.

Tabel 11.

Rasio Tingkat Efektifitas Keuangan Daerah Kota Magelang 2014-2018

\begin{tabular}{|c|c|c|c|}
\hline Tahun & Realisasi Pad & Target Pad & Rasio Efektivitas \% \\
\hline 2014 & $164,927,631,230$ & $124,432,498,000$ & 132.54 \\
\hline 2015 & $186,677,410,081$ & $152,805,995,000$ & 122.17 \\
\hline 2016 & $220,315,848,702$ & $197,465,478,000$ & 111.57 \\
\hline 2017 & $233,557,714,356$ & $218,085,185,000$ & 107.09 \\
\hline 2018 & $249,877,424,347$ & $225,916,332,000$ & 110.61 \\
\hline Rata-Rata & & & 116.80 \\
\hline
\end{tabular}

Sumber : data sekunder yang diolah 
Berdasarkan tabel diatas dapat diketahui bahwa rasio efektivitas kota Magelang mengalami fluktuasi cenderung turun. Rata-rata tingkat efektifitas kota Magelang tahun anggaran 2014 sampai dengan 2018 sebesar $116,80 \%$ yang berarti termasuk dalam kategori sangat efektif. Hal ini menggambarkan tingkat kemampuan daerah semakin baik.

5. Pemetaan Keuangan dengan Indeks Kemampuan Keuangan (IKK) dan Metode Kuadran

Adapun Kemampuan keuangan daerah diukur dengan menghitung rata-rata dari indeks share, growth dan elastisitas, dengan demikian akan terlihat bagaimana peta keuangan kota Magelang. Setelah mengetahui bagaimana kondisi kemampuan keuangan daerah kota Magelang maka kita dapat mengetahui pada kuadran mana kondisi keuangan kota Magelang. Adapun hasil pengolahan dari indeks share, growth, dan elastisitas adalahh sebagai berikut:

a. Growth

Growth adalah ukuran yang menunjukkan seberapa besar kemampuan pemerintah daerah dalam mempetahankan dan meningkatakan keberhasilanya dalam memperoleh pendapatan asli daerah (PAD) dari periode ke periode. Hasil pengukuran indeks growth dapat dilihat pada tabel 12 .

Tabel 12

Indeks Growth

\begin{tabular}{|c|c|c|c|c|}
\hline Tahun & Growt & Kondisi Max & Kondisi Min & Indeks \\
\hline 2014 & 288.397 & $1,763.783$ & 288.397 & 0.000 \\
\hline 2015 & 858.296 & $1,763.783$ & 288.397 & 38.627 \\
\hline 2016 & 654.953 & $1,763.783$ & 288.397 & 24.845 \\
\hline 2017 & $1,763.783$ & $1,763.783$ & 288.397 & 100.000 \\
\hline 2018 & $1,531.139$ & $1,763.783$ & 288.397 & 84.232 \\
\hline \multicolumn{5}{|c|}{ Jumlah } \\
\hline
\end{tabular}

Sumber: Data Sekunder yang Diolah 
Dengan hasil perhitungan table 12 pada tahun 2014-2018 kota Magelang memiliki rata-rata growth sebesar 49,541

b. Share

Share adalah indikator ukuran untuk mengukur seberapa jauh kemampuan daerah untuk membiayai kegiatan rutin dan belanja pembangunan daerah.

Tabel 13.

Indeks Share

\begin{tabular}{|c|c|c|c|c|}
\hline Tahun & Share & Kondisi Max & Kondisi Min & Indeks \\
\hline 2014 & 24.175 & 26.658 & 24.175 & 0.000 \\
\hline 2015 & 25.352 & 26.658 & 24.175 & 47.405 \\
\hline 2016 & 25.270 & 26.658 & 24.175 & 44.086 \\
\hline 2017 & 26.559 & 26.658 & 24.175 & 95.993 \\
\hline 2018 & 26.658 & 26.658 & 24.175 & 100.000 \\
\hline \multicolumn{5}{|c|}{ Jumlah } \\
\hline \multicolumn{5}{|c|}{ Rata-Rata } \\
\hline
\end{tabular}

Sumber : diolah, 2020

Berdasarkan hasil perhitungan pada tabel 13 menunjukkan kota Magelang memiliki rata- rata sebesar 57,497 .

c. Indeks elastisitas

Elastisitas adalah ukuran yang mengambarkan sensitivitas atau elastisiatas PAD terhadap perkembangan ekonomi. Nilai yang menunjukan elastisitas pertumbuhan PAD terhadap pertumbuhan ekonomi di kota Magelang sebagai salah satu indikator keberhasilan pemerintah bisa dilihat dari hasil rata-rata indeks elastisitas. Adapun hasil perhitungan indeks elastisitas dapat dilihat pada tabel 14.

Tabel 14.

Indeks Elastisitas

\begin{tabular}{|c|c|c|c|c|}
\hline Tahun & Elastisitas & Kondisi Max & Kondisi Min & Indeks \\
\hline 2014 & 1.728371 & 1.728371 & 0.307027 & 100.000 \\
\hline 2015 & 0.595673 & 1.728371 & 0.307027 & 20.308 \\
\hline
\end{tabular}




\begin{tabular}{|c|c|c|c|c|}
\hline Tahun & Elastisitas & Kondisi Max & Kondisi Min & Indeks \\
\hline 2016 & 0.797799 & 1.728371 & 0.307027 & 34.529 \\
\hline 2017 & 0.307027 & 1.728371 & 0.307027 & 0.000 \\
\hline 2018 & 0.356922 & 1.728371 & 0.307027 & 3.510 \\
\hline \multicolumn{5}{|r|}{ Jumlah } \\
\hline \multicolumn{2}{|c|}{ Rata-Rata } & 158.347 \\
\hline
\end{tabular}

Sumber : diolah, 2020

Dengan hasil perhitungan pada tabel 14 menunjukan rata-rata indeks elastisitas sebesar 31,669.

Adapun dari hari hasil pengukuran indeks Growth, Share dan elastisitas maka di peroleh rata-rata indeks kemampuan keuangan daerah kota Magelang.

Hasil perhitungan indeks kemampuan keuangan daerah kota Magelang tahun anggaran 2014-2018 dapat dilihat pada tabel 15.

Tabel 15.

Indeks Kemampuan Keuangan Daerah Tahun 2014-2018

\begin{tabular}{|c|c|c|c|}
\hline Indeks Growt & Indeks Share & Indeks Elastisitas & Ikk \\
\hline 49.541 & 57.497 & 31.669 & 46.236 \\
\hline
\end{tabular}

Dilihat dari hasil perhitungan Indeks kemampuan keuangan kota Magelang tahun anggaran 2014 sampai dengan 2018, skala indeks kemampuan keuangan daerah menunjukkan angka 46,236\%. Ini berarti kemampuan keuangan kota Magelang tergolong tinggi. Peta Kemampuan Keuangan berdasarkan metode kuadran dengan kondisi masing-masing tercantum dalam tabel 16.

Tabel 16.

Peta Kemampuan Keuangan Daerah Berdasarkan Metode Kuadran

\begin{tabular}{|l|l|l|}
\hline & \multicolumn{2}{|c|}{ Rata-rata growth (\%) } \\
\hline \multirow{4}{*}{$\begin{array}{l}\text { Rata-rata } \\
\text { Share (\%) }\end{array}$} & KUADRAN II & KUADRAN I \\
\cline { 2 - 3 } & Share : Rendah & Share : Tinggi \\
\cline { 2 - 3 } & Growth: Tinggi & Growth : Tinggi \\
\cline { 2 - 3 } & KUADRAN IV & KUADRAN III \\
\cline { 2 - 3 } & Share : Rendah & Share : Tinggi \\
\cline { 2 - 3 } & Growth: Rendah & Growth : Rendah \\
\hline
\end{tabular}

Sumber: Bapenas 2003 
Berdasarkan peta kemampuan keuangan daerah dengan metode kuadran maka dapat dikelompokkan status kemampuan keuangan dengan kriteria atau kondisi seperti pada tabel 17.

Tabel 17.

Klasifikasi Status Kemampuan Keuangan

\begin{tabular}{|c|l|}
\hline KUADRAN & KONDISI \\
\hline I & $\begin{array}{l}\text { Kondisi paling ideal. PAD mengambil peran besar dalam } \\
\text { total belanja, dan daerah mempunyai kemampuan } \\
\text { mengembangkan potensi lokal. Kondisi ini ditunjukkan } \\
\text { dengan besarnya nilai share dan growth yang tinggi. }\end{array}$ \\
\hline II & $\begin{array}{l}\text { Kondisi ini belum ideal, tetapi daerah mempunyai } \\
\text { kemampuan mengembangkan potensi lokal sehingga PAD } \\
\text { berpeluang memiliki peran besar dalam Total Belanja. } \\
\text { Sumbangan PAD terhadap Total Belanja masih rendah } \\
\text { namun pertumbuhan (growth) PAD tinggi. }\end{array}$ \\
\hline III & $\begin{array}{l}\text { Kondisi ini juga belum ideal. Peran PAD yang besar dalam } \\
\text { Total Belanja mempunyai peluang yang kecil karena }\end{array}$ \\
& $\begin{array}{l}\text { pertumbuhan PAD nya kecil. Sumbangan PAD terhadap } \\
\text { Total Belanja tinggi, namun pertumbuhan PAD rendah. }\end{array}$ \\
\hline IV & $\begin{array}{l}\text { Kondisi ini paling buruk. Peran PAD belum mengambil } \\
\text { peran yang besar dalam Total Belanja, dan daerah belum } \\
\text { mempunyai kemampuan mengembangkan potensi lokal. } \\
\text { Sumbangan PAD terhadap Total Belanja dan } \\
\text { pertumbuhan PAD rendah }\end{array}$ \\
\hline
\end{tabular}

Sumber: Bapenas 2003

Dari hasil perhitungan share dan growth terhadap ringkasan anggaran pendapatan dan belanja daerah kota Magelang tahun anggaran 2014 sampai dengan 2018, maka diperoleh data share sebesar $57.497 \%$ dan growth sebesar $49.541 \%$ kemudian dengan pemetaan kemampuan keuangan daerah berdasarkan metode kuadran, posisi kota Magelang berada pada kuadran III, yaitu Kondisi ini juga belum ideal. Peran PAD yang besar dalam Total Belanja mempunyai peluang yang kecil karena pertumbuhan PAD nya kecil. Sumbangan PAD terhadap Total Belanja tinggi, namun pertumbuhan PAD rendah.

\section{SIMPULAN DAN SARAN}

Berdasarkan analisis kinerja keuangan daerah Kota Magelang tahun 2014-2018 menggunakan indeks dan peta kemampuan keuangan daerah maka dapat ditarik 
kesimpulan bahwa berdasarkan nilai indeks kemampuan keuangan daerah skala indeks menunjukkan angka 46.236. Ini berarti kemampuan keuangan kota Magelang tergolong tinggi. Tingginya tingkat kemampuan keuangan pemerintah daerah kota Magelang disebabkan oleh besarnya bantuan keuangan dari pemerintah pusat.

Berdasarkan peta kemampuan keuangan daerah yang dihitung dari hasil perhitungan share dan growth terhadap ringkasan anggaran pendapatan dan belanja daerah kota Magelang tahun 2014 sampai dengan 2018, maka diperoleh data share $57.497 \%$ dan growth sebesar $49.541 \%$. kemudian dengan pemetaan kemampuan keuangan daerah berdasarkan metode kuadran, posisi kota Magelang berada pada kuadran III, yaitu Kondisi ini juga belum ideal. Peran PAD yang besar dalam Total Belanja mempunyai peluang yang kecil karena pertumbuhan PAD nya kecil. Sumbangan PAD terhadap Total Belanja tinggi, namun pertumbuhan PAD rendah.

Penelitian ini hanya dilakukan dengan tujuan untuk menganalisis kinerja dan kemampuan keuangan yang didasarkan pada Laporan Realisasi Anggaran Pendapatan dan Belanja Daerah yang diteliti, dan penelitian ini dilakukan pada pemerintah Kota Magelang, sehingga kesimpulan ini hanya berlaku bagi Pemerintah Kota Magelang. Penelitian ini juga membatasi lima tahun pengamatan yaitu dari tahun 2014- 2018, sehingga masih perlu diuji kembali pada tahun-tahun mendatang.

Pemerintah Kota Magelang disarankan agar meningkatkan pengelolaan terhadap potensi yang ada, karena dengan seperti itu mampu membawa dampak yang besar, tidak hanya bagi peemrintah tetapi juga bagi masyarakat. Pemanfaatan potensi di Kota Magelang sangat bragam antara lain bidang pariwisata, Kesehatan, budaya, perdagangan, dan Pendidikan. Apabila pemerintah berhasil memaksimalkan potensi tersebut dengan baik, maka pajak yang berperan utama dalam meningkatkan Pendapatan Asli Daerah akan semakin meningkat. Dalam hal ini, pemerintah berperan dengan cara memberikan informasi yang rinci kepada masyarakat tentang kewajiban mereka sebagai pembayar pajak dan retribusi. Pemerintah juga perlu melakukan pengawasan terhadap pihak yang terkait dengan 
pemungutan pajak dan retribusi supaya tidak terjadi kecurangan. Karena besarnya pajak dan retribusi tidak hanya sebagai komponen utama untuk meningkatkan $P A D$, tetapi juga sebagai tolok ukur tingkat kesejahteraan masyarakat. Untuk penelitian selanjutnya, bisa membandingkan evaluasi kinerja dan kemmampuan keuangan dengan dua daerah yang memiliki karakteristik yang sama ataupun berbeda.

\section{DAFTAR PUSTAKA}

Indrawati, L. R., \& Panggiarti, E. K. (2017). Perspektif Pajak Daerah Bagi Pendapatan Asli Daerah Kota Magelang. Jurnal REP (Riset Ekonomi Pembangunan), 2(1), 139-150. https://doi.org/10.31002/rep.v2i2.229

Mutiha, A. (2016). Analisis Kinerja Keuangan Pemerintah Daerah Kota Bogor Tahun Anggaran 2010 -2014. Jurnal Vokasi Indonesia, 4(2). https://doi.org/10.7454/jvi.v4i2.101

Muhibtari, A. N. (2014). Analisis Rasio Keuangan Anggaran Pendapatan Dan Belanja Daerah Kota Magelang Untuk Menilai Kinerja Keuangan Pemerintah Daerah Kota Magelang Tahun Anggaran 2008-2012. c, 1-43. https://doi.org/10.16526/j.cnki.114762/tp.2014.11.051

Wahyudi, M., \& Wulandari, E. (2017). Kinerja Keuangan Pemerintah Daerah dalam Era Otonomi Daerah (Studi Kasus Pemerintah Daerah Kota Magelang). Jurnal RAK (Riset Akuntansi Keuangan), 2(3), 26-32.

Anggaran, T., \& Pandawa, J. (2016). Analisis Kinerja Keuangan Pemerintah Daerah Kabupaten Sukoharjo Tahun Anggaran 2011-2013. 1(1), 40-54.

Laksmi, D. N. (2016). Kontribusi Komponen Pendapatan Asli Daerah (PAD) Terhadap Realisasi PAD Tahun Anggaran 2006-2015 Kota Magelang. 6, 1939.

Melatunan, M. Y., \& Pinatik, S. (n.d.). ANALISIS KINERJA KEUANGAN PEMERINTAH DAERAH KOTA SORONG Jurnal EMBA Vol . 7 No . 3 Juli 2019 , Hal . 4134- 4143. 7(3), 4134-4143.

Mokodompit, Sandy Paramitha., Sifrid S. Pangemanan., \& Inggriani, E. (2016). ANALISIS KINERJA KEUANGAN PEMERINTAH DAERAH KOTA KOTAMOBAGU. Jurnal EMBA, $4(2), 5-37$.

Fitriani, Ni Luh Putu., \& A. A. N. . D. (2014). PENILAIAN KINERJA KEUANGAN DAERAH KABUPATEN/KOTA DI PROVINSI BALI TAHUN 2007-2011. E-Jurnal Akuntansi Universitas Udayana, 1, 211-227.

Ropa, M. O. (2016). Analisis kinerja keuangan pemerintah kabupaten minahasa selatan. Jurnal EMBA, 4(2), 738-747.

Winarna, J. (2010). Analisis Kinerja Keuangan Pemerintah Daerah Kabupaten/Kota Di Jawa Tengah Periode 2012-2014. Journal of Rural and Development, 1(2).

https://doi.org/10.1017/CBO9781107415324.004 
Korompot, R., \& Warongan, J. (2017). Analysis of Financial Performance in the Government of North Sulawesi. Accountability, 6(2), 9-19.

https://doi.org/10.32400/ja.17755.6.2.2017.9-19

Purba, I. B. A. H., \& Mimba, N. P. S. H. (2019). Analysis on the Regional Financial Performance of Regencies / Cities in Bali Province. Journal Of Humanities And Social Science, 24(1), 20-33. https://doi.org/10.9790/0837-2401092033

Akbar, R. (2018). Pengukuran Kinerja dan Akuntabilitas Publik di Indonesia Studi Awal di Pemerintah Daerah. Jurnal Akuntansi Dan Akuntabilitas Publik, 1(1), 1-16. https://doi.org/10.22146/jaap.35332

Ulimpa, Y. S., Sondakh, J. J., \& Runtu, T. (2018). Analisis Pengukuran Kinerja Pemerintah Daerah Dalam Era Otonomi Daerah Di Kabupaten Sorong Provinsi Papua Barat. Going Concern: Jurnal Riset Akuntansi, 14(1), 302-307.

https://doi.org/10.32400/gc.13.04.21105.2018 